\title{
PENGEMBANGAN KURIKULUM DI INDONESIA MENGHADAPI TUNTUTAN KOMPETENSI ABAD 21
}

\section{Budi Agus Sumantri*}

\begin{abstract}
Abstrak: Abad 21 menuntut berbagai keterampilan yang harus dikuasai seseorang, sehingga diharapkan pendidikan dapat mempersiapkan siswa dan guru untuk menguasai kompetensikompetensi abad 21, agar dapat menyesuaikan diri dengan perkembangan zaman. Di abad 21 pendidikan ditantang untuk dapat menciptakan pendidikan yang dapat menghasilakan sumberdaya pemikir yang mampu ikut membangun tatanan sosial dan ekonomi melalui pengembangan kurikulum sesuai dengan tuntutan kompetensi abad 21. Melalui pengembangan kurikulum diharapkan peserta didik dan guru memiliki kecakapan, keterampilan, dan kompetensi abad 21 yang mencakup: Communication skill, Collaboration skill, Critical thingking and problem solving skill, Creativity and innovation skill. Penulisan karya ilmiah ini dilakukan dengan menggunakan studi pustaka dengan menelusuri berbagai rujukan yang terkait dengan topik utama permasalahan. Keberhasilan sebuah kurikulum itu tergantung kepada guru, bagaimana guru mengelola dan mengembangkan kurikulum melalui proses pembelajaran yang afektif dan efisien, sehingga dapat menghasikan lulusan yang bertakwa kepada Tuhan yang Maha Esa, cakap menggunakan teknologi dan informasi, terampil dalam berkomunikasi, memiliki etos kerja yang tinggi, produktif, inovatif dan kreatif.
\end{abstract}

Kata Kunci: Pengembangan, kurikulum, Kompetensi Abad 21

* Program Pascasarjana Prodi Pendidikan Agama Islam Fakultas Tarbiyah dan Keguruan Universitas Islam Negeri Sunan Kalijaga Yogyakarta. Jalan Laksada Adisucipto, Caturtunggal, Kec Depok, Kabupaten Seleman, Daerah Istimewa Yogyakarta, 089673866892, budisumanti0045@gmail.com. 


\section{Pendahuluan}

7 engaruh perkembangan ilmu pengetahauan dan teknologi terhadap pendidikan adalah memberikan materi atau bahan 1 yang akan disampaikan dalam proses pendidikan serta
menuntut lembaga pendidikan untuk mampu memberikan pengetahuan, keterampilan baru yang akan dikembangkan melalui pengembangan kurikulum (Muhammad Zaini 2009, 56) Keberhasilan suatu kurikulum itu sangat tergantung kepada bagaimana kurikulum itu dilaksanakan atau diimplementasikan. Sebaik apa pun kurikulum itu di rancang, namun apabila di dalam pelaksanaanya tidak didukung oleh berbagai macam unsur maka akan sulit mencapai hasil yang diharapkan.

Abad 21 ditandai dengan berkembangnya teknologi, komunikasi dan informasi yang pesat. Sehingga dalam kehidupan di abad-ke 21 ini menuntut berbagai keterampilan yang harus dikuasai sehingga pendidikan dapat mempersiapkan siswa untuk menguasai berbagai keterampilan tersebut agar menjadi pribadi yang suskses dalam hidup. (Estitika Yuni Wijaya dkk 2016, 263). Dengan memahami kurikulum pendidik dapat memilih dan menentukan tujuan pembelajaran, metode, tehnik, media dan alat evaluasi pengajaran yang sesuai dan tepat untuk mencapai tujuan yang diinginkan.

Maka perlu adanya pengembangan kurikulum yang sesuai dengan kebutuhan dan perkembangan zaman, sesuai dengan tuntutan kompetensi abad ke-21. Berangkat dari masalah ini untuk lebih jelasnya pengembangan kurikulum menghadapi tuntutan kompetensi abad ke-21 akan dibahas dalam makalah ini.

\section{Perspektif global dalam pengembangan kurikulum}

Dalam era globalisasi ditandai dengan fenomena terjadinya proses perubahan hubungan antar bangsa dan antar negara tanpa terkait oleh batas geo-sosial politik atau geo nasional ideologis. Seluruh dunia cenderung menjadi satu dan membentuk saling tergantungan tanpa mengenal batasan-batasan yang jelas, apa pun sifat batas-batas tersebut. Globalisasi tidak hanya terjadi dalam 
bidang ilmu pengetahuan, teknologi, dan seni (ipteks), tetapi juga dalam bidang politi ekonomi, sosial, dan budaya, termasuk bidang pendidikan. Hal ini memiliki implikasi terhadap peranan guru sebagai wahana untuk melahirkan lulusan yang produktif, kreatif, inovatif, dan afektif dengan memiliki kemampuan serta daya saing tinggi (M. Hosnan 2014, 2).

Di abad 21, para siswa mengahadapi berbagai resiko dan ketidak pastian sejalan dengan perkembangan lingkungan yang begitu pesat, seperti teknologi, ilmu pengetahuan, ekonomi dan sosial budaya sehingga siswa dituntut untuk belajar lebih banyak dan proaktif agar mereka memiliki pengetahuan dan keterampilan/ keahlian yang memeadai. Para siswa saat ini hidup dalam dunia yang berbedah dan jauh lebih kompek dibanding zaman sebelumnya. Guru sebagai ujung tombak atau sebagai sosok terdepan (frontliner) didalam proses pendidikan, dituntut mampu memberikan pengetahuan, sikap, prilaku, dan keterampilan, melalui strategi dan pola pembelajaran yang sesuai dengan tuntutan dan perkembangan abad 21 (M. Hosnan 2014, 2). Oleh karena itu, sudah menjadi kewajiban bagi para guru untk memberikan bekal kepada peserta didik agar bisa hidup dimasa depan. Salah satu upaya untuk mempersiapkan siswa menghadapi zaman global ini yaitu dengan mengembangkan kurikulum sekolah yang memuat perspektif global.

Kurikulum yang bercorak perspekti global adalah kurikulum yang yang juga memuat wawasan global, bukan hanya nasional ataupun lokal. Kurikulum tersebut harus mampu membawa siswa untuk berpikir global dalam arti siswa mampu mengungkapkan informasi sebanyak mungkin dan informasi tersebut dapat digunakan sebagai pajangan yang mengarahkan mereka menjadi warga negara yang produktif dan menjadi insan yang mempunyai kepedulian sosial terhadap orang lain di sekitarnya, mampu bekerja sama, saling ketergantungan secara harmonis (Suryanto 2006, 8). 


\section{Aktivitas dan Model Pembelajaran Abad 21}

Dalam aktivitas/kegiatan belajar, guru harus menyadari bahwa setiap orang mempunyai cara yang optimal dan berbeda-beda untuk mempelajari dan memahami informasi baru, bahwa siswa perlu diajarkan cara-cara yang lain dari metode belajar standar yang telah dialaminya untuk memaksimalkan informasi yang dapat mereka pahami dalam kegiatan belajar mengajar (Suryanto 2006, 82). Oleh karena itu, guru dituntut untuk senantiasa menyempurnakan dan menyesuaikan kurikulum dengan perkembangan ilmu pengetahuan teknologi, dan seni, serta tuntutan kebutuhan lokal, nasional, dan global, sehingga kurikulum yang dikembangkan disekolah betulbetul diperlukan oleh peserta didik sesuai dengan kebutuhan lingkungan, perkembangan jaman, serta tuntuan dan beban tugas yang akan dilakukan setelah mengikuti pembelajaran (E. Mulyasa 2006, 7).

Keberhasilan kurikulum sangat dipengaruhi oleh kemempuan guru yang akan menerapkan dan mengaktualisasikannya dalam pembelajaran. Kemampuan, serta tugas yang dibebankan kepadanya. Tidak jarang kegagalan penerapan kurikulum disebabkan oleh kurangnya pengetahuan, keterampilan guru dalam memahami tugas-tugas yang harus dilaksanakannya (E. Mulyasa 2006, 6). Oleh karena itu untuk mencapai tujuan dalam suatu pendidikan yang sesuai dengan perkembangan zaman, perlunya bagi seorang pendidik mengetahui model dan karakteristik dari pembelajaran abad 21.

\section{Tipe-Tipe Belajar}

Peneliti gaya belajar Water Barbed dan Raymond Swassing memberikan tiga jenis persepsi sensoris (cara untuk mengingat) yang kita gunakan dalam tingkat yang beragam semua ini (dalam Cyntia Ulrich Tobias,2009:86). Adapun tipe-tipe belajar yang paling mudah dikenali sebagai berikut (E. Mulyasa 2006, 83) : 


\section{Tipe Audiotori}

Audiotori merupakan cara belajar dengan cara mendengarkan petunjuk lisan atau belajar dengan cara mendengarkan. Seorang auditori tidak harus selalu mendengar berkali-kali untuk mengingat sesuatu, tetapi dengan mendengarkan ucapan dirinya sendiri tentang informasi yang harus diingat kedalam memori seefektif mungkin. Jika unsur auditori sangat kuat, maka secara otomatis orang tersebut akan membacanya (bukan dalam hati) seakan-akan berbicara sendiri dengan dirinya untuk memastikan bahwa orang tersebut memahaminya.

\section{Tipe Visual}

Visual merupakan belajar dengan melihat dan mengamati, mengkaitkan yang sedang dipelajari denagn sesuatu yang kelihatan. Orang visual terbiasa untuk membayangkan apa yang sedang dipelajari, basanya sering dianggap sedang melamun. Orang yang visualnya lebih dominan lebih mudah belajar apabila kata-kata atau konsep yang harus dipahami dikaitkan dengan sesuatu. Ketika membaca atau mengingat-ingat sesuatu, pelajar yang visual tak henti-hentinya membayangkan rupa benda itu. Kadaang kala, menggambarkan sesuatu yang jahu berbeda dari kenyataan.

\section{Tipe Kinestetik}

Kinestetik merupakan belajar dengan melibatkan anggota tubuh, apa yang sedang dipelajari diperagakan. Orang kinestetik hampir selalu bergerak, sering dianggap orang yang tak pernah diam. Anak kinestetik sangat perlu bergerak sewaktu mempelajari sesuatu. Kalau tidak bergerak, apa yang dipelajari sulitmelekat sekalipun hanya gerakan sederhana, seperti mengitari ruangan atau belajar kesana kemari, anak-anak dengan tipe ini akan lebih mudah menghafal atau belajar dibandingkan duduk diam. 


\section{Model/Karakteristik Pembelajaran Abad 21}

Strategi pembelajaran yang diimplementasikan oleh guru di dalam kelas harus mempunyai beberapa karakteristik, antara lain (1) pembelajaran berpusat pada peserta didik (student centered), (2) mengembangkan kreativitas peserta didik, (3) Menciptakan suasana yang menarik, menyenangkan, dan bermakna, (4) mengembangkan beragam kemampuan yang bermuatan makna dan nilai, (5) belajar melalui berbuat yakni peserta didik aktif berbuat (6) menekankan pada penggalian, penemuan, dan penciptaan serta (8) menciptakan pembelajaran dalam situasi yang nyata dan konteks sebenarnya yakni melalui pendekatan kontekstual (E. Mulyasa 2006, 85).

Pergeseran paradigma pembelajaran kontemporer telah berganti pada student centered (pembelajaran berpusat pada siswa), yaitu siswa yang berperan aktif dalam proses pembelajaran, dimana guru tidak lagi sebagai satu-satunya pusat informasi, melainkan sebagai manajer dan fasilitator, sebagai pengelola pembelajaran yang memfasilitasikegiatan pembelajaran. Dengan demikian siswa diberikan kebebasan dan keleluasaan belajar yang sesuai dengan minat, bakat, dan kebutuhan mereka serta siswatersebut dapat mengukur sendiri sejahu mana pengalaman dan penguasaan mereka terhadap suatu materi (E. Mulyasa 2006, 86). Keterampilan yang dibutuhkan siswa, diantaranya sebagai berikut:

\section{Bertaqwa Kepada Tuban Yang Maha Esa}

Kecakapan intelektual, digital sosial, dan akademik belum cukup. Siswa disekolah wajib memiliki kecakapan hidup yang lebih bernilai yang ditandai dengan keterampilan beriman dan bertakwa, terampil hidup jujur, terampil menjalankan amanah, terampil berbuat adil, terampil menjalankan tanggung jawab, terampil berempati, dan patuh menjalankan hidup beragama sebagai refleksi menjalankan perintah Tuhan.

\section{Memiliki Karakter Sebagai Pemikir}

Karakter pemikir ini ditandai dengan terampil berfikiri inovatif lewat kecepatan beradaptasi dengan lingkungan, maupun 
memecahkan masalah yang kompleks, dan dapat mengendalikan diri sendiri dalam menghadapi tantangan yang ada, cerdas, kreatif, dan berani mengambil resiko. Selain itu, karakter yang relevan denagn kerja otak ini meliputi perilaku berpikir yang selalu ingin tahu, berpikir terbuka, dan bersikap reflektif.

\section{Cakap Dalam Mengembangkan Teknologi Dan Informasi}

Siswa diharapkan memiliki kemampuan dan kecakapan unutk memvisualkan informasi dalam mengembangkan keterampilan multikultural, bekerja sama dan berkomunikasi dalam ruang lintas bangsa, serta terampil mengembangkan kesadaran global.

\section{Memiliki keterampilan berkomunikasi}

Siswa diharapkan memiliki kemampuan bekerja dalam tim yang bervariasi, berkolaborasi dan cakap mengembangkan hubungan interpersoanal sehingga selalu dapat menempatkan diri dalam interaksi yang harmonis. Memiliki kecakapan komunikasi personal, sosial, dan terampil mengejawantahkan tanggung jawab. Yang tidak kalah pentingnya adalah terampil dalam komunikasi interaktif dengan dan rendah hati.karakter yang relevan dengan keterampilan ini adalah menghargai, toleran, peduli. Suka menolong, gotong royong , nasionalis, kosmopolit, mengutamakan kepentingan umum dan bangga terhadap produk bangsa sendiri.

\section{Memiliki Etos Kerja Yang Tinggi Dan Produktif}

Siswa diharapkan memiliki kemampuan unutk menentukan prioritas, mengembangkan perencanaan, memetakan hasil pencapaian, terampil menggunakan perangkat kerja, dan meningkatkan keterampilan yang sejalan dengan perkembangan teknologi. Di samping menghasilkan mutu produk yang tinggi, karakter yang relevan dengan hal ini adalah perilaku yang bersih dan sehat, disiplin, sportif, tidak kenal menyerah, tangguh, handal, berketetapan hati, kerja keras, dan kompetitif.

Tuntutan dunia masa depan menuntut anak untuk memiliki kecakapan berpikir dan belajar. Kecakapan tersebut diantaranya 
adalah kecakapan pemecahan masalah (problem solving skill), kecakapan berpikir keritis (critical tingking skill), klaborasi (callboration skill), kecakapan berkomunikasi (communication skill), kecakapan kreativitas (creativity and innovation skil) (E. Mulyasa 2006, 87).

Model pembelajaran yang diharapkan dikembangkan untuk era kekiniaan/abad 21 adalah sebagai berikut:

\section{Communication skill}

Pada model ini, siswa dituntut untuk memahami, mengelola, dan menciptakan komunikasi yang efektif dalam berbagai bentuk dan isi secara lisan, tulisan, dan multimedia. Siswa diberikan kesempatan menggunakan kemampuannya untuk menggunakan ide-idenya, baik itu ketika berdiskusi dengan teman-temannya maupun menyelesaikan masalah dari gurunya.

\section{Collaboration skill}

Pada model ini, siswa menunjukan kemampuan dalam kerja sama kelompok dan kepemimpinan, beradaptasi dalam berbagai peran dan tanggung jawab, bekerja secara produktif dengan yang lain, merupakan empati pada tempatnya, menghormati perspektif berbeda. Siswa siswa juga menjalankan tanggung jawab pribadai dan fleksibilitas secara pribadi, pada tempat belajar dan hubungan masyarakat, menetapkan dan mencapai standar dan tujuan yang tinggi untuk diri sendiri dan orang lain, memaklumi kerancuan .

\section{Critical thingking and problem solving skill}

Pada model ini, siswa berusaha untuk memberikan penalaran yang masuk akal dalam memahami dan membuat pilihan yang rumit, memahami interkoneksi antar sistem. Siswa juga menggunakan kemampuan yang dimilikinya untuk berusaha menyelesaikan permasalahan yang dihadapinya denagn mandiri, siswa juga memiliki kemampuan untuk menyusun dan mengungkapkan, menganalisis, dan menyelesaikan masalah. 


\section{Creativity and innovation skill}

Model dan metode serta keterampilan yang akan digunakan dalam pembelajaran masa kini dituntut untuk lebih bersifat multimodel dan multimetode dan real world problem, sehingga model pembelajaran berbasis proyek lebih banyak ditutut. Metode proyek adalah tanda gerakan yang progresif. Para pemelajar belajar dengan berbuat, dan pemelajaran mereka ditunjukan oleh penyelesaian proyek penyelidikan. Proyek didiasarkan pada pengalaman menawarkan pilihan kepada siswa, dan kiranya lebih memotivasi dari pada mendapatkan informasi yang ditransmisikan ke seorang pemelajar yang pasif (Susan M. Drake 2013, 10). Proses pembelajaran lebih berpusat pada siswa serta meninggalkan perlakuan yang bersifat menyamakan semua siswa, tetapi lebih bersifat individual. Kecakapan multiinteligensi menuntut guru untuk mampu mengakomodasi semua perbedaan yang dimiliki siswa. Pembelajaran yang kompetitif bergeser menjadi pembelajaran yang kolaboratif.

\section{Peran Dan Tantangan Guru Pada Abad Ke-21}

Keberhasilan pelaksanaan kegiatan belajar mengajar sangat tergantung pada guru, karena guru merupakan ujung tombak dalam proses pembelajaran. Bagaimanapun sempurnanya sebuah kurikulum, tanpa didikung oleh kemampuan guru, maka kurikulum itu hanya sesuatau yang tertulis dan tidak memiliki makna (M. Hosnan 2014, 166). Dalam Undang-Undang Repiblik Indonesia No. 14 Tahun 2005 tentang guru dan dosen bahwa profesi guru merupakan pekerjaaan bidang khusus yang dilaksanakan berdasarkan prinsip, memiliki bakat, minat, komitmen, kualifikasi akademik, tanggung jawab, memiliki kesempatan mengembangkan mengembangkan profesinya. Seperti yang telah dikemukakan diatas bahwa guru mempunyai peranan yang sangan penting dalam prosese belajar mengajar dimana guru dituntut untuk terus meningkatkan kualitasnya dalam dunia pendidikan.

Adapun guru sebagai elemen utama dalam pendidikan memiliki peran sebagai berikut (M. Hosnan 2014, 166): 


\section{Peran guru sebagai perencana pembelajaran}

Keberhasilan dalam implementasi kurikulum dapat dipengaruhi perencanaan pembelajaran yang disusun guru. Kepiawaian guru dalam menyusun rencana pembelajaran dapat menentukan keberhasilan pencapaian kompetensi yang harus diserap oleh peserta didik.

\section{Guru sebagai pengelolah pembelajaran}

Tujuan dari pengelolaan pembelajaran adalah terciptanya kondisi lingkungan belajar yang kondusif dan menyenangkan bagi siswa sehingga dalam proses pembelajaran siswa tidak merasa terpaksa apalagi tertekan. Peran guru sebagai pengelola pembelajaran menciptakan iklim pembelajaran sebagai wadah interaksi sosial maupun psikologi.

\section{Guru sebagai fasilitator}

Sebagai fasilitator, tugas guru adalah membantu untuk mempermudah siswa belajar, bukan hanya memberikan berbagai pengetahuan dan memaksa siswa untuk menelannya. Dengan demikian guru perlu memahami karakteristik siswa, termasuk gaya belajar, kebutuhan kemampuan dasar yang dimiliki siswa. Melalui pemahaman itu guru dapat melayani dan memfasilitasi setiap siswa sesuai dengan minta, bakat, dan kelemahan-kelemahan yang dimilikinya.

\section{Peran guru sebagai evaluataor}

Guru sebagai evaluator tidak kalah pentingnya dengan peran yang lain. Dilihat dari fungsi evaluasi, guru dapat mengetahui tngkat keberhasilan peserta didik, menegtahui kelemahan dalam pembelajaran dan untuk menentukan tahapan belajar berikutnya. Dengan adanya evaluasi, baik itu formatif maupun sumantif, keduanya bermanfaat untuk mengatisipasi permasalahan yang muncul. 
Dengan semakin pesatnya berkembangnya ilmu pengetahuan dan teknologi pada abad 21ini, tuntutan guru semakin kompleks mengingat semakin banyaknya variabel yang harus ditangani guru dalam proses pendidikan yang baik menyangkut administrasi sekolah maupun keterampilan mengelola siswa sehingga mereka dapat belajar dengan baik dan tertib.

\section{Kompetensi Guru Untuk Menghadapi Tantangan Guru Abad $\mathrm{Ke}-21$}

Dalam menghadapi tantangan kemajuan ilmu pengetahuan dan teknologi, guru profesional sudah selayaknya harus dapat menyesuaikan diri dengan tuntutan tersebut (M. Hosnan 2014, 174). Oleh karena itu, perlu adanya upaya yang dilakukan untuk meningkatkan kualitas guru dalam mengembangkan berbagai aspek-aspek pendidikan dan pembelajaran.

Secara umum pendidikan abad 21 didominasi oleh pendidikan yang berbasis ICT, kompetensi inti seperti membaca, menulis dan berhitung yang diperoleh selama mengikuti pendidikan akan menjadi dasar kompetensi lainya, keterampilam yang dibutuhkan pada abad 21 meliputi: 1) learning innovation skill, 2) information, median and technology skill, 3) life and carrer skill. tiga keterampilan tersebut dapat berkembang, jika sekolah memiliki lingkungan kerja yang memadai untuk belajar dan berinovasi, menyediakan program (kurikulum) peningkatan guru serta memberi penilaian yang memacu guru untuk berprestasi (M. Hosnan 2014, 178).

Guru yang cerdas akan mampu berpikir kritis dalam memecahkan masalah serta kreatif dan inovatif dalam bekerja. Jika kompetensi tersebut disertai dengan kemampuan berkomunikasi efektif (mampu menyampaikan atau menerima gagasan secar lisan dan tertulis ) serta mampu bekerja sama dengan orang lain, maka tantangan sebesar apapun niscaya akan bisa dilalui oleh guru. Menurut Suyatno (2007), guru profesional adalah guru yang selalu berubah dari prktik lama, bahkan mau dan mampu meninggalkan metode dan resep-resep sukses di masa lampau untuk mengahadapi berbagai tantanga masa kini dan masa yang akan datang. 
Karakteristik keterampilan yang diperlukan guru abad 21 dapat diuraikan sebagai berikut (M. Hosnan 2014, 178):

a. Learning and inovation adalah orang mau belajar dan berinovasi secara terus menerus. Ciri-ciri orang mau belajar dan berinovasi adalah dapat berpikir kritis dalam memecahkan masalah, kreatif dan inovatif dalam bekerja, dapat berkomunikasi secara efektif dan mampu bekerja sama atau berkolaborasi dengan teman sejawat, kolega maupun atasan.

b. Digitsl literacy adalah orang yang mampu menguasai teknologi digital, seperti mengetahui banyak informasi, menguasai berbagai macam media digital dan menguasai ICT.

c. Career and life adalah orang yang beroreantasi pada karier dan kehidupan bermasyarakat. Orang yang beroreantasi kehidupan akan memiliki ciri-ciri fleksibel/luwes dalam bergaul dan mudah menyesuaikan diri terhadap perubahan, memiliki inisiatif dan dapat mengarahkan pada diri sendiri (self-direction), dapat berinteraksi lintas sosial dan budaya. Orang yang beroreantasi pada karir akan memiliki produktivitas dan akuntabilitas kerja yang tinggi serta memiliki jiwa kepemimpinan dan tanggung jawab.

Untuk menghadapi tantangan abad 21 dari ketiga hal di atas masih terdapat 10 (sepuluh) kompetensi yang diharapkan untuk masa depan, antara lain:

a. Kemampuan berkomunikasi.

b. Kemampuan berpikir jernih dan kritis.

c. Kemampuan mempertimbangkan segi moral suatu permasalahan.

d. Kemampuan menjadi warga negara yang bertanggung jawab.

e. Kemampuan mencoba untuk mengerti dan toleran terhadap pandangan yang berbeda.

f. Kemampuan hidup dalam masyarakat yang mengglobal.

g. Memiliki minat luas dalam kehidupan.

h. Memiliki kesiapan untuk bekerja.

i. Memiliki kecerdasan sesuai dengan bakat/ minatnya.

j. Memiliki rasa tanggung jawab terhadap lingkungan. 
Berdasarkan kajian arah perkembangan teknologi dandan rencana strategis pemerintah yang bedampak pada sekolah, berikut hal-hal yang harus dipelajari guru untuk menyiapkan diri dalam menghadapi abad 21(M. Hosnan 2014, 176):

\section{Invenity Thinking.}

Kesuksesan berkarier dapat dicapai dengan cara kerja keras, pada umumnya, orang yang sukses adalah orang yang be.kerja melebihi apa yang ditugaskan kepada dirinya. Selain bekerja keras, sukses juga dicapai dengan kemampuan berpikir kritis dan kreatif dalam pekerjaan yang ditekuninya. Bebrapa kompetensi kerja yang perlu ditingkatkan oleh guru untuk mencapai kesuksesan dia abad 21 adalah sebagai berikut.

a. Adaptability. Kemampuan beradaptasi dengan perubahan teknologi, lingkungan sosial budaya, dan kebijakan pemerintah. Jika terdapat perubahan-perubahan kebijakan, maka teknologi dan peraturan, guru segera dapat menyesuaikan diri.

b. Curiosity. Memiliki rasa ingin tahu dan ingin belajar terhadap hal-hal yang baru. Guru dituntut segera mempelajari teknologi baru dan meninggalkan teknologi lama yang sudah tidak relevan lagi dengan kebutuhan sekarang.

c. Creativity. Kemampuan untuk menggunakan imajinasi, daya pikir untuk menciptakan karya baru khususnya karya teknologi yang berguna untuk pembelajaran maupun masyarakat luas

d. Risk-taking. Keberanian mengambil resiko. Orang-orang yang berani mengambil resiko adalah orang yang dapat menyelesaikan masalah dengan kreatif (creative problem solving) dan berpikir logis sehingga menghasilkan keputusan yang kuat.

\section{Digital Age Literacy}

Teknologi informasi dan komunikasi membawah dampak besar dalam kehidupan manusia khususnya di dunia pendidikan. Guru yang dapat berkembang di masa depan adalah guru yang menguasai teknologi informasi dan komunikasi karena banyak ilmu 
pengetahuan dan teknologi dapat diakses dari media ini. Pada abad 21, melek ICT (information and communication technology literacy). Lebih baik dari pada memiliki keterampilan tejnologi saja. Oleh karena itu guru diharapkan mengikuti perkembangan tejnologi digital supaya dapat mengajarkan keterampilan yang sama dengan keterampilan yang dibutuhkan dunia.

\section{Effective communication}

Di masa depan, dunia kerja menuntut semua kegiatan berjalan efektif, termasuk efektif dalam berkomunikasi. Untuk mencapai komunikasi efektif, guru diharapkan belajar bekerja sama.

a. Teaning. Bekerja sama dalam tim atau kelompok dalam berkomunikasi efektif orang dapat menerima gagasan orang lain dan tidak memaksakan gagasanya untuk diterima orang lain. Dengan demikian, akan terjadi saling hormat menghormati antar sesama anggota tim.

b. Collaboration and interpersonal skill. Guru diharapkan mampu berkolaborasi atau bekerja sama dengan pihak lain, meskipun manfaat atau hasil yang diperoleh dari kerja sama tersebut berbeda.

c. Personal and social responsibility. Komunikasi efektif dapat dibangun dari orang-orang yang yang tidak mementingkan dirinya sendiri atau dengan kata lain, memiliki kepedulian terhadap kehidupan sosial.

d. Interactive communication. Dalam kehidupan sosial, guru yang dapat berkembang adalah guru yang mau berinteraksi dengan lingkungan sosialnya.

\section{Pengembangan Kurikulum Di Indonesia Menghadapi Tuntutan Pada Abad 21}

Abad 21 ditandai sebagai abad keterbukaan atau abad globalisasi, artinya kehidupan manusia pada abad 21 mengalami perubahan-perubahan yang fundamental yang berbeda dengan tata kehidupan sebelumnya. Dikatakan abad 21 adalah abad yang meminta kualitas dalam segala usaha dan hasil kerja manusia. 
Dengan sendirinya abad ke 21 meminta sumberdaya manusia yang berkualitas, yang dihasilkan oleh lembaga-lembaga yang dikelola secara profesional sehingga membuahkan hasil unggulan. Tuntutan-tuntutan yang seraba baru tersebut meminta terobosan dalam berpikir, penyesuaian konsep dan tindakan-tindakan. Dengan kata lain diperlukan suatu paradigma baru dalam menghadapi tantangan yang baru (Estitika Yuni Wijaya, dkk 2016, 263)

Dalam dunia pendidikan perlu dikaji beberapa kemungkinan kurikulum yang bisa diterapkan di sekolah sebagai upaya untuk mencari pendekatan pemecahan masalah pendidikan, khususnya masalah pengembangan kurikulum disekolah yang lebih cocok diterapkan di era skarang dan masa depan. Maka dalam hal ini ada beberapa kurikulum yang dapat diterapkan dalam pembelajaran di sekolah, yang diharapkan dari kurikulum ini dapat menjawab permasalahan-permasalahan dalam duina pendidikan dan mempersiapkan siswa untuk bisa menghadapi tuntutan kompetensi abad 21.

\section{Kurikulum berbasis kompetensi dan karakter}

Kurikulum berbasis kompetensi dan karakter atau yang lebih dikenal dalam kurikulum nasional dengan kurikulum 2013. Abad 21 telah mengubah paradigma belajar di dunia, yakni dari paradigma teaching menjadi paradigma learning. Pada abad sebelumnya lebih dikenal paradigma teaching, dimana guru menjadi pusat belajar. Sedangkan pada paradigma learning justru siswa yang menjadi pusat dalam pembelajaran (Solih Hidayat 2013, 122).

UNESCO telah menjabarkan dalam empat visi pendidikan abad 21 yang lebih mendasarkan pada para digma learning (Indrajati Sidi: 2011). Keenpat visi itu adalah:

a. Learning to think (belajar berpikir, beroreantasi pada pengetahuan logis dan rasional). Belajar mengetahui merupakan kegiatan untuk memperoleh, memperdalam dan memanfaatkan materi pengetahuan. Penguasaan materi merupakan salah satu hal penting bagi siswa di abad ke-21. 
Siswa juga harus memiliki kemauan untuk belajar sepanjang hayat. Hal ini berarti siswa harus secara berkesinambungan menilai kemampuan diri tentang apa yang telah diketahui dan terus merasa perlu memperkuat pemahaman untuk kesuksesan kehidupannya kelak. Siswa harus siap untuk selalu belajar ketika menghadapi situasi baru yang memerlukan keterampilan baru (Siti Zubaidah, 2018).

b. Learning to do (belajar berbuat atau belajar hidup, beroreantasi pada bagaimana mengatasi suatu masalah). Agar mampu menyesuaikan diri dan beradaptasi dalam masyarakat yang berkembang sangat cepat, maka individu perlu belajar berkarya. Siswa maupun orang dewasa sama-sama memerlukan pengetahuan akademik dan terapan, dapat menghubungkan pengetahuan dan keterampilan, kreatif dan adaptif, serta mampu mentrasformasikan semua aspek tersebut ke dalam keterampilan yang berharga.

c. Learning to be (belajar menjadi diri sendiri, beroreantasi pada pembentukan karakter). Keterampilan akademik dan kognitif memang keterampilan yang penting bagi seorang siswa, namun bukan merupakan satu-satunya keterampilan yang diperlukan siswa untuk menjadi sukses. Siswa yang memiliki kompetensi kognitif yang fundamental merupakan pribadi yang berkualitas dan beridentitas. Siswa seperti ini mampu menanggapi kegagalan serta konflik dan krisis, serta siap menghadapi dan mengatasi masalah sulit di abad ke-21. Secara khusus, generasi muda harus mampu bekerja dan belajar bersama dengan beragam kelompok dalam berbagai jenis pekerjaan dan lingkungan sosial, dan mampu beradaptasi dengan perubahan zaman.

d. Learning to live together (belajar hidup bersama, beroreantasi untuk bersikap toleran dan siap bekerja sama). Berbagai bukti menunjukkan bahwa siswa yang bekerja secara kooperatif dapat mencapai level kemampuan yang lebih tinggi jika ditinjau dari hasil pemikiran dan kemampuan untuk menyimpan informasi dalam jangka waktu yang panjang dari pada siswa 
yang bekerja secara individu. Belajar bersama akan memberikan kesempatan bagi siswa untuk terlibat aktif dalam diskusi, senantiasa memantau strategi dan pencapaian belajar mereka dan menjadi pemikir kritis.

Sementara itu, draf kurikulum 2013 mengadopsinya kedalam model pembelajaran yang akan dijadikan rujukan utama dalam kurikulum baru. Dalam penjelasannya pada abad ke 21 telah terjadi pergeseran paradigma. Pergeseran itu ditentukan oleh empat hal penting yang menjadiciri utama pembelajaran di era baru, yaitu (Solih Hidayat 2013, 123):

Tabel.1 Pergeseran Paradigma Belajar Abad 21

\begin{tabular}{|c|l|}
\hline Ciri Abad 21 & \multicolumn{1}{|c|}{ Model Pembelajaran } \\
\hline $\begin{array}{c}\text { Informasi: tersedia dimana } \\
\text { saja dan kapan saja }\end{array}$ & $\begin{array}{l}\text { Pembelajaran diarahkan } \\
\text { untuk mendorong peserta } \\
\text { didik mencari tahu bukan } \\
\text { diberi tahu) dari berbagai } \\
\text { sumber observasi }\end{array}$ \\
\hline $\begin{array}{c}\text { Komputasi: penggunaan mesin } \\
\text { untuk mempercepat } \\
\text { pekerjaan }\end{array}$ & $\begin{array}{l}\text { Pembelajaran diarahkan } \\
\text { untuk mampu merumuskan } \\
\text { masalah (menanya), bukan } \\
\text { hanya menyelesaikan } \\
\text { masalah (menjawab) }\end{array}$ \\
\hline $\begin{array}{c}\text { Otomasi: menjangkau segala } \\
\text { pekerjaan rutin. }\end{array}$ & $\begin{array}{l}\text { Pembelajaran diarahkan } \\
\text { untuk melatih berpikir } \\
\text { analitis (pengambilan } \\
\text { keputusan), bika berpikir } \\
\text { mekanistis (rutin) }\end{array}$ \\
\hline $\begin{array}{c}\text { Komunikasi: dari mana saja } \\
\text { kemana saja. }\end{array}$ & $\begin{array}{l}\text { Komunikasi (mudah } \\
\text { dilakukan, dari mana saja dan } \\
\text { kapan saja). }\end{array}$ \\
\hline
\end{tabular}

Maka dalam kegiatan pembelajaran kurikulum ini diarahkan untuk memberdayakan semua potensi yang dimiliki peserta didik agar mereka dapat memiliki kompetensi yang diharapkan melalui upaya menumbuhkan dan mengembangkan, sikap/attitude, 
pengetahuan/knowledge, dan keterampilan/skill. kualitas lain yang dikembangkan kurikulum dan harus terealisasikan dalam proses pembelajaran, antara lain kreativitas, kemandirian, kerja sama, solidaritas, kepemimpinan, empati toleransi dan kecakapan hidup peserta didik guna membentuk watak serta meningkatkan peradaban dan martabat bangsa (M. Hosnan 2014, xi).

Dalam implementasinya kurikulum 2013, memerankan guru sebagai pembentuk karakter dan kompetensi peserta didik, yang harus kreatif memilah dan memilih, serta mengembangkan metode dan materi pelajaran. Guru harus profesional dalam membentuk karakter dan kompetensi peserta didik sesuai dengan karakteristik individual masing-masing (E. Mulyasa 2006, 5). Sehingga guru dapat dapat melahirkan karya-karya inovatif, serta , mengoptimalkan segala pikiran dan kreativitasnya dalam mengelola kelas dan pembelajaran yang diampuhnya (E. Mulyasa 2006, 4). Dengan demikian pada tabel.1 menunjukan posisi kurikulum kurikulum 2013 yang terntegrasi, untuk mendukung terwujudnya tujuan pengembangan kurikulum sesuai dengan kompetensi abad 21. Maka dibutuhakan proses pembelajaran yang mendukung kreativitas, itu sebabnya perlunya merumuskan kurikulum nyang megedepankan pengalaman personal melalui proses menghayati, menanya, menalar, dan mencoba (obsevation based leearning) melalui collaborative learniang (Solih Hidayat 2013, 123).

\section{Kurikulum Beroreantasi Pada Kecakapan Hidup}

Konsep kecakapan hidup sejak lama menjadi perhatian parah ahli dalam pengembangan kurikulum. Tyler dan Taba misalnya, mengemukakan kecakapan hidup dan bekerja merupakan slah satu fokus analisis dalam pengembangan kurikulum. Kurikulum beroreantasi kecakapan hidup $(\mathrm{KBKH})$ dapat diartikan sebagai suatu program kegiatan dan pengalaman belajar yang berisi tentang berbagai kecakapan hidup untuk meningkatkan kemampuan, kesanggupan, dan keterampilan yang diperlukan oleh seseorang dalam menghadapi masalah-masalah kehidupan agar dapat menjaga 
kelangsungan hidup dan pengembangan dirinya (Solih Hidayat 2013, 244-245).

Dengan demikian pengembangan kurikulum yang beroreantasi kecakapan hidup itu harus menggambarkan aspek-aspek: a) kompetensi yang relevan untuk dikuasai peserta didik, b) materi pembelajaran sesuai dengan tingkat perkembangan peserta didik, c) kegiatan pembelajaran untuk menguasai kompetensi, d) fasilita, alat dan sumber belajar yang menunjang dan memadai, dan e) kompetensi yang dapat diaktualisasikan dalam pola kehidupan pesertadidik sehari-hari. Kecakapan hidup akan memiliki makna yang luas apabila kegiatan pembelajaran yang dirancang memberikan dampak positif bagi peserta didik dalam membantu memecahkan problematika kehidupanya (Solih Hidayat 238, 2013).

Secara khusus pendidikan kecakapan hidup bertujuan untuk (Solih Hidayat 2013, 241) :

a. Mengaktualisasikan potensi peserta didik sehingga dapat digunakan untuk memecahkan problem yang dihadapi.

b. Memberikan wawasan yang luas mengenai pengembangan karier peserta didik.

c. Memmberikan bekal dengan latihan dasar tentang tentang nilainilai yang berkaitan dengan kehidupan sehari-hari.

d. Memberikan aset kualitas batiniah, sikap dan perbuatan lahiriah peserta didik melalui pengenalan, penghayatan, dan penerapan nilai kehidupan sehari-hari sehingga dapat menjaga kelangsungan hidup dan perkembanganya.

Secara subtantif, ruang lingkup, kecakapan hidup meliputi aspek-aspek: kemampuan, kesanggupan, dan keterampilan. Aspek kemampuan dan kesanggupan tercangkup dalam kecakapan berpikir, sedangkan aspek keterampilan tercangkup dalam kecakapan bertindak (Solih Hidayat 2013, 242). Pengembangan kurikulum yang berbasis kompetensi dan karakter (competency and character based curriculum, diharakan dapat membekali peserta didik dengan berbagai kemampuan dan tuntutan zaman, serta perkembangan teknologi dan seni, guna menjawab tantangan arus globalisasi, berkontribusi pada pembangunan masyarakat dan 
kesejahteraan sosial, lentur dan adaptif terhadap berbagai perubahan.

Dari beberapa jenis kurikulum diatas jelas bahwa setiap kurikulum memiliki kelebihannya masing-masing, yang dikembangkan berdasarkan potensi, kompetansi dan kondisi peserta didik, sehingga dari pengembangan kurikulum diharapkan bisa membantu mencapai tujuan pendidikan dan mempersiapkan peserta didik dalam menghadapi tantangan kompetensi abad 21.

\section{Model-Model Pembelajaran Abad 21}

\section{Student Centered Learning (SCL)}

Student centered learning adalah pembelajaran yang berpuasat pada siswa yang menekankan pada minat, kebutuhan dan kemampuan individu, menjajikan model belajar yang menggali motivasi instrinsik untuk membangun masyarakat yang suka dan selalu belajar. Model belajar ini sekaligus dapat mengembangkan kualitas sumber daya manusia yang di butuhkan masyarakat, seperti kreativitas, kepemimpinan, rasa percaya diri, kemandirian, kedisiplinan, kekeritisan dalam berpikir, kemampuan berkomunikasi dan bekerja dalam tim, keahlian teknis, serta wawasan global untuk dapat selalu beradaptasi terhadap perubahan dan perkembangan zaman (M. Hosnan 2014, 193).

\section{Active Learning}

Pembelajaran aktif merupakan strategi pembelajaran yang lebih banyak melibatkan peserta didik dalam mengakses berbagai informasi dan pengetahuan untuk dibahas dan dikaji dalam proses pembelajaran di kelas, sehingga mereka mendapatkan berbagai pengalaman yang dapat meningkatkan kompetensinya. Selain itu, belajar aktif juga memungkinkan peserta didik dapat mengembangkan kemampuan analisis dan sintesis serta mampu merumuskan nilai-nilai baru yang diambil dari hasil analisis mereka sendiri (Hasan Baharun 2015, 37). 
Secara harfiah active learning maknanya adalah belajar aktif. Kebanyaka praktisi dan pengamat menyebutnya sebagai strategi learning by doing. Pendekatannya, memandang belajar sebagai proses membangun pemahaman lewat pengalaman dan informasi. Dengan pendekatan ini, persepsi, pengetahuan dan perasaan peserta didik yang unik ikut mempengaruhi proses pembelajaran. Pendekatan active learning merupakan istilah dalam dunia pendidikan yaitu sebagai strategi belajar mengajar yang bertujuan untuk meningkatkan mutu pendidikan. Dan untuk mencapai keterlibatan siswa agar efektif dan efisien dalam belajar membutuhkan berbagai pendukung dalam proses belajar mengajar. Misalnya dari sudut siswa, guru, situasi belajar, program belajar dan dari sarana belajar. Pengertian tersebut menunjukkan bahwa metode active learning menempatkan siswa sebagai inti dalam kegiatan belajar mengajar. Siswa dipandang sebagai objek dan sebagai subjek. Active learning merupakan suatu proses belajar mengajar yang aktif dan dinamis (Hasan Baharun 2015, 37).

\section{Catatan Akhir}

Kurikulum yang bercorak perspekti global adalah kurikulum yang yang juga memuat wawasan global, bukan hanya nasional ataupun lokal. Kurikulum tersebut harus mampu membawa siswa untuk berpikir global dalam arti siswa mampu mengungkapkan informasi sebanyak mungkin dan informasi tersebut dapat digunakan sebagai pajangan yang mengarahkan mereka menjadi warga negara yang produktif dan menjadi insan yang mempunyai kepedulian sosial terhadap orang lain di sekitarnya, mampu bekerja sama, saling ketergantungan secara harmonis.

keterampilam yang dibutuhkan pada abad 21 meliputi: 1) learning innovation skill, 2) information, median and technology skill, 3) life and carrer skill. tiga keterampilan tersebut dapat berkembang, jika sekolah memiliki lingkungan kerja yang memadai untuk belajar dan berinovasi, menyediakan program (kurikulum) peningkatan guru serta memberi penilaian yang memacu guru untuk berprestasi. 
Keberhasilan sebuah kurikulum itu tergantung kepada guru, bagaimana guru mengelola dan mengembangkan kurikulum melalui proses pembelajaran yang afektif dan efisien, sehingga dapat menghasikan lulusan yang bertakwa kepada Tuhan yang Maha Esa, cakap menggunakan teknologi dan informasi, terampil dalam berkomunikasi, memiliki etos kerja yang tinggi, produktif, inovatif dan kreatif.

\section{Daptar Pustaka}

Baharun, Hasan. 2015. Penerapan Pembelajaran Aktive Learning Untuk Meningkatkan Hasil Belajar Di Madrasah. Pedagogik Jurnal Pendidikan 1 (1).

Drake, Susan. M. 2013. Menciptakan Kurikulum Yang Terintegrasi Yang Berbasis Standar. Jakarta: PT Indeks.

Estitika Yuni Wijaya, dkk,. 2016. Transformasi Pendidikan Abad 21 Sebagai Tuntuan Pengembangan Sumber Daya Manusia Di Era Global. Prosiding Seminar Nasional Pendidikan Matematika 1. Hidayat, Solih. 2013. Pengembangan Kurikulum Baru, Bandung: PT Remaja Rosdakarya.

Hosnan, M. 2014. Pendekatan Saintifik dan kontekstual Dalam Pembelajaran Abad 21. Bogor: Galia Indonesia.

Mulyasa, M. 2006. Kurikulum Yang Disempurnakan; Pengembangan

Standar Kompetensi Dan Kompetensi Dasar. Bandung: Remaja Rosdakarya.

Suryanto. 2006. Persoalan Imlementasi Kurikulum. Jakarta: Kompas. Zaini, Muhammad. 2009. Pengembangan Kurikulum (Konsep Implementasi Evaluasi Dan Inovasi). Yogyakarta: Teras.

Zubaidah, Siti. Keterampilan Abad Ke-21: Keterampilan Yang Diajarkan Melalui Pembelajaran, https://www.researchgate. net/publication/318013627_KETerampilan_Abad_Ke21_Ke terampilan_Yang_Diajarkan_Melalui_Pembelajaran. Di akses 30 November 2018 Pukul 10:01. 